\title{
Aktivitas Antibakteri dan Skrining Fitokimia Beberapa Tanaman Berkhasiat Obat di Kota Kendari
}

\section{(Antibacterial Activity and Phytochemical Screening of Some Medicinal Plants in Kendari City)}

\author{
Musadar Mappasomba ${ }^{1}$, Muhammad Hajrul Malaka ${ }^{2}$, Rini Hamsidi ${ }^{3}$, La Ode Muhammad Andi \\ Zulbayu $^{4}$, Sahidin ${ }^{*}$ \\ ${ }^{1}$ Fakultas Pertanian Universitas Halu Oleo, Kampus Hijau Bumi Tridharma, Jl. H. E. A. Mokodompit \\ Kendari 93232 \\ ${ }^{2}$ Fakultas Farmasi Universitas Halu Oleo, Kampus Hijau Bumi Tridharma, Jl. H. E. A. Mokodompit \\ Kendari 93232 \\ ${ }^{3}$ Program Studi D3 Pengobatan Tradisional Fakultas Vokasi Universitas Airlangga, Jl. Dharmawangsa \\ Dalam No. 28-30, Surabaya 60286 \\ ${ }^{4}$ Jurusan Farmasi STIKES Mandala Waluya Kendari, Jl. A. H. Nasution no. G-37 Kendari 93231 \\ E-mail: sahidin02@uho.ac.id
}

\author{
Article Info: \\ Received: 13 March \\ 2020 \\ Accepted: 4 April 2020 \\ DOI: \\ 10.33772/pharmauho.v \\ 6 i1.11445
}

\begin{abstract}
Medicinal plants are traditionally used for the treatment of human infections, and could be an excellent source of drugs to fight off antibiotic resistance. The present study was undertaken to explore tamarin (Tamarindus indica L.), bitter melon (Momordica charantia L.), bilimbi (Averrhoa bilimbi L.), Malay apple (Syzygium malaccense L.), and celery (Apium graveolens L.) from Kendari, South East Sulawesi, for their potential activity against bacteria. Methanolic extracts of roots, barks, and leaves of tamarin, bitter melon, bilimbi, Malay apple, and celery were subjected to a test of their antimicrobial properties by disk diffusion method against Escherichia coli ATCC
\end{abstract} 35219 and Staphylococcus aureus ATCC 2592 with chloramphenicol as selected antibiotics. Phytochemical screening showed alkaloids, flavonoids, tannins, saponins from various extract. Among the five medicinal plants, the highest potential was observed in the root and bark extracts of Malay apple and the root extract of A. bilimbi against E. coli with zone of inhibition at $15 \mathrm{~mm}, 13 \mathrm{~mm}$, and $15 \mathrm{~mm}$, respectively. Meanwhile, the methanolic extract of the root and bark of Malay apple displayed the highest activity against $\mathrm{S}$. aureus with inhibition zone at $13 \mathrm{~mm}$ and $15 \mathrm{~mm}$. The study suggested the possibility to explore the antibacterial bioactive for the treatment of infectious diseases.

Keywords: antibacterial, phytochemical, Kendari, medicinal plants, Sulawesi 
yaitu ekstrak akar belimbing wuluh, akar jambu bol, dan batang jambu bol dengan diameter zona hambat masingmasing $15 \mathrm{~mm}, 15 \mathrm{~mm}$, dan $13 \mathrm{~mm}$. Selain itu, aktivitas antibakteri yang paling aktif terhadap $S$. aureus adalah ekstrak batang dan akar jambu bol dengan diameter zona hambat masing-masing $13 \mathrm{~mm}$ dan $15 \mathrm{~mm}$.

Kata kunci: antibakteri, fitokimia, Kendari, obat tradisional, Sulawesi Tenggara

\section{Pendahuluan}

Sulawesi Tenggara terdiri dari berbagai macam suku bangsa, memiliki keunikan flora tersendiri apabila dibandingkan dengan keanekaragaman flora di wilayah kepulauan lainnya di Indonesia, serta memberikan kontribusi penting terhadap keragaman etnobotani [1]. Etnobotani tumbuhan obat yang mencakup etnomedis pada etnis masyarakat pada wilayah tertentu merupakan penggunaan berbagai tumbuhan obat mulai dari akar, batang, daun, bunga, buah, dan biji serta hasil eskresi dan khasiat yang dimiliki [2]. Masyarakat Suku Muna dan Buton merupakan masyarakat lokal Sulawesi Tenggara yang telah memanfaatkan berbagai tumbuhan obat dan terbukti secara empiris mampu mengatasi beberapa penyakit infeksi [3]. Oleh karena itu studi pengetahuan, sikap dan tindakan terhadap penggunaan obat tradisional bagi masyarakat dapat ditawarkan melalui optimalisasi budidaya melalui kebun Tanaman Obat Keluarga (TOGA) [4]. Hal ini didukung oleh masyarakat yang mulai banyak memilih bahan alami untuk penyembuhan penyakit karena efek samping lebih ringan dari pengobatan secara medis [5].

Penyakit infeksi merupakan salah satu masalah kesehatan masyarakat yang utama di negara maju dan berkembang [6]. Contoh bakteri penyebab infeksi adalah Staphylooccus aureus yang menyebabkan infeksi pada saluran pernapasan dan Escherichia coli yang menyebabkan diare. Kedua bakteri tersebut merupakan flora normal dan bersifat oportunis [7]. Data penyakit menular yang disebabkan oleh bakteri untuk periode prevalensi infeksi saluran pernapasan akut (ISPA) berdasarkan diagnosis tenaga kesehatan dan keluhan penduduk adalah 25\% persen dan untuk periode prevalensi diare adalah 3,5\% di seluruh provinsi di Indonesia. Daerah Sulawesi Tenggara khususnya untuk penyakit ISPA sebesar $22,2 \%$ dan penyakit diare sebesar 7,3 persen [8]. Dinas Kesehatan Provinsi Sulawesi Tenggara menyebutkan jumlah kasus dan penderita diare di Provinsi Sulawesi Tenggara tahun 2012 berjumlah 96.644 kasus dari total penduduk 2.310 .083 jiwa. Total diare yang ditangani tahun 2012 sebesar $60.48 \%$. Bahkan di tahun 2016 ISPA dan diare termasuk kasus terbanyak dalam kejadian penyakit infeksi [9].

Paria (Momordica charantia L.), seledri (A. graveolens L.), belimbing wuluh (Averrhoa bilimbi L.), asam (Tamarindus indica L.), dan jambu bol
(Syzygium malaccense L. Merr) adalah jenis tanaman obat yang umumnya dikonsumsi dan terdapat di area budidaya perkebunan masyarakat. Secara empiris, asam bermanfaat sebagai obat tradisional untuk mengatasi asma dan batuk [10], seledri sebagai antihipertensi [11], dan paria sebagai anitipiretik [12], jambu bol memiliki aktivitas antidiabetes maupun antioksidan [13], serta belimbing wuluh bermanfaat sebagai antipiretik [14]. Oleh karena itu, penelitian ini dilakukan untuk mengidentifikasi golongan senyawa dan menguji aktivitas antibakteri beberapa bagian tanaman obat dengan metode difusi agar untuk melihat keragaman kajian aktivitas biologinya.

\section{Metode}

\subsection{Umum}

Sampel tanaman obat diperoleh dari kebun budidaya masyarakat di wilayah Kecamatan Poasia dan Kambu, Kota Kendari, Sulawesi Tenggara. Bakteri uji merupakan koleksi Laboratorium Farmasi Universitas Halu Oleo.

\subsection{Penyiapan Sampel dan Ekstraksi}

Preparasi dilakukan dengan memotong-motong sampel yang sebelumnya telah dibersihkan, selanjutnya dikeringkan menggunakan cahaya matahari sampai sampel benar-benar tidak memiliki kadar air lagi kemudian diblender hingga menjadi serbuk. Semua serbuk tersebut ditimbang dari tiap-tiap bagian tanaman (batang, daun, akar) dan disimpan dalam wadah kaca untuk pengerjaan selanjutnya. Serbuk dari masing-masing bagian tanaman lalu diekstraksi dalam wadah tertutup selama $3 \times 24$ jam menggunakan pelarut metanol. Pemisahan residu dan filtrat dilakukan setiap 1x24 jam dilakukan penggantian pelarut yang sama sehingga diperoleh filtrat. Filtrat dikumpulkan dan dipekatkan dengan rotary vacuum evaporator hingga diperoleh ekstrak kental.

\subsection{Penapisan Fitokimia}

Uji fitokimia dengan KLT dilakukan dengan menggunakan plat silika $\mathrm{GF}_{254}$. Ekstrak dari masingmasing tanaman ditotolkan pada jarak $\pm 1 \mathrm{~cm}$ dari tepi bawah plat dengan pipa kapiler kemudian dikeringkan dan dielusi dengan fase gerak kloroform-metanol 
(9:1). Setelah gerakan fase gerak sampai pada garis batas, elusi dihentikan. Noda-noda pada permukaan plat diperiksa di bawah sinar UV pada panjang gelombang $254 \mathrm{~nm}, 366 \mathrm{~nm}$ dan sinar tampak, kemudian diberikan reagen penguji untuk masingmasing golongan senyawa. Reagen penguji masingmasing golongan senyawa adalah sebagai berikut:

a. Golongan senyawa alkaloid disemprot pereaksi Dragendorff untuk mendeteksi yang menunjukkan bercak coklat-jingga [15]

b. Golongan senyawa flavonoid diuapi dengan amoniak akan menghasilkan warna biru kehijauan [16]

c. Golongan senyawa tanin dengan penyemprot $\mathrm{FeCl}_{3} 1 \%$ menghasilkan warna lembayung $[13,16]$

d. Golongan senyawa saponin diuji dengan cara dikocok dalam tabung reaksi salaam 10 detik sampai terebntuk busa yang stabil [13].

e. Golongan senyawa triterpenoid disemprotkan dengan pereaksi Lieberman-Buchard menghasilkan warna merah keunguan [13]

\subsection{Uji Aktivitas Antibakteri}

\section{Penyiapan media}

Media Nutrient Agar (NA) digunakan untuk pertumbuhan bakteri. Media disiapkan dengan cara menimbang media NA sebanyak 23 gram, dilarutkan dalam $1000 \mathrm{~mL}$ air suling dalam erlenmeyer dan dipanaskan menggunakan hot plate sampai mendidih dan larut sempurna kemudian disterilkan dalam autoklaf pada suhu $121^{\circ} \mathrm{C}$ selama 15 menit [18].

\section{Penyiapan kultur bakteri}

Bakteri uji yang digunakan adalah E. coli ATCC 35218 dan S. aureus ATCC 25923. Bakteri tersebut kemudian diremajakan dengan cara memindahkan 1 ose ke media agar miring dan diinkubasi selama 24 jam pada suhu $37 \pm 2^{\circ} \mathrm{C}$ [18]. Bakteri yang akan diuji disuspensikan dengan cara memasukkan bakteri uji dalam $\mathrm{NaCl}$ fisiologis $0,9 \%$. Kekeruhan bakteri diukur hingga sesuai dengan standar McFarland 0,5 menggunakan spektronik 20D pada $\lambda 625 \mathrm{~nm}$ [19].

\section{Uji aktivitas antibakteri}

Uji aktivitas antibakteri menggunakan metode difusi agar (well diffusion method) dengan kertas cakram (disk) berdiameter $6 \mathrm{~mm}$. Bakteri uji digores pada permukaan nutrient agar padat, kemudian kertas cakram yang telah diberi $20 \mu \mathrm{L}$ masing-masing zat uji diletakkan diatas permukaan nutrient agar tersebut (18). Pada penelitian ini, kontrol negatif menggunakan kertas cakram yang telah ditetesi pelarut sedangkan kontrol positif menggunakan obat antibakteri yang beredar di pasaran (kloramfenikol). Aktivitas antibakteri diukur berdasarkan diameter zona hambat yang terbentuk. Diameter zona hambat diukur menggunakan mikrometer atau jangka sorong. Pengujian dilakukan sebanyak 3 kali untuk setiap ekstrak.

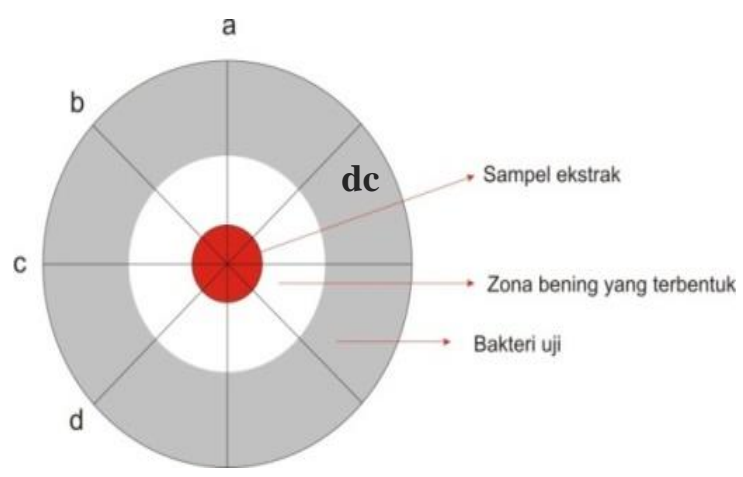

Pengukuran diameter zona hambat $=\frac{a+b+c+d}{4}$

Kriteria penetapan aktivitas antibakteri yaitu antibakteri aktif dan sangat aktif (zona hambatan $>11$ $\mathrm{mm}$ ), aktif sedang (zona hambatan 6-11 mm), dan tidak aktif (zona hambatan $<6 \mathrm{~mm}$ ) [20].

\section{Hasil dan Pembahasan}

Ekstraksi dengan cara maserasi digunakan dalam penelitian ini karena memiliki keuntungan yaitu dapat mencegah terurainya senyawa-senyawa metabolit pada sampel yang tidak tahan terhadap pemanasan. Pelarut yang digunakan dalam proses maserasi ini adalah metanol. Metanol dipilih sebagai pelarut karena kemampuannya dalam menarik senyawa kimia baik yang bersifat polar dan nonpolar sehingga senyawa yang diyakini bersifat aktif didalam simplisia dapat diperoleh maksimal.

Uji profil fitokimia pada penelitian ini dilakukan dengan metode KLT. Berdasarkan identifikasi golongan metabolit sekunder yang menunjukan bahwa metabolit sekunder hampir di semua tamanan hal ini dapat dilihat pada Tabel 2.

Berdasarkan Tabel 2, golongan senyawa yang ada dari masing-masing bagian tanaman tersebut, mayoritas kandungan senyawa adalah flavonoid dan tanin yang didasarkan pada hasil penyemprotan maupun penguapan pereaksi penanda pada spot hasil elusi dari masing-masing bagian tanaman dengan menggunakan eluen kloroform: metanol (9:1). Belimbing banyak mengandung senyawa fenolik antara lain flavonoid, glikosida, maupun fenolik [25]. 
Tabel 1. Hasil serbuk, ekstrak dan perhitungan rendamen sampel tanaman

\begin{tabular}{llccc}
\hline \multicolumn{1}{c}{ Tanaman } & \multicolumn{1}{c}{ Sampel } & Berat Serbuk Simplisia $(\mathbf{g})$ & Berat Ekstrak $(\mathbf{g})$ & Rendamen $(\%)$ \\
\hline Belimbing Wuluh & Akar & 46,30 & 2,62 & 5,65 \\
& Batang & 95,31 & 3,76 & 3,94 \\
Seledri & Daun & 90,45 & 3,16 & 3,49 \\
& Akar & 25,28 & 1,32 & 5,22 \\
\multirow{5}{*}{ Jambu bol } & Batang & 30,21 & 1,54 & 5,09 \\
& Daun & 28,72 & 1,49 & 5,32 \\
\multirow{5}{*}{ Paria } & Akar & 90,28 & 3,09 & 3,42 \\
& Batang & 97,35 & 3,28 & 3,36 \\
\multirow{5}{*}{ Asam } & Daun & 80,34 & 2,94 & 3,65 \\
& Akar & 16,49 & 2,07 & 12,55 \\
& Batang & 18,28 & 2,65 & 14,49 \\
& Daun & 28,06 & 4,11 & 14,64 \\
& Akar & 20,52 & 2,67 & 13,01 \\
\end{tabular}

Tabel 2. Hasil uji golongan senyawa metabolit sekunder

\begin{tabular}{llccccc}
\hline \multirow{2}{*}{ Tanaman } & \multicolumn{5}{c}{ Sampel } & \multicolumn{5}{c}{ Hasil Penapisan } \\
\cline { 2 - 7 } Belimbing Wuluh & Akar & Alkaloid & Flavonoid & Tanin & Saponin & Triterpenoid \\
& Batang & - & - & + & - & - \\
\multirow{5}{*}{ Seledri } & Daun & - & - & + & - & - \\
& Akar & - & + & - & - & - \\
\multirow{5}{*}{ Jambu bol } & Batang & - & - & - & - & - \\
& Daun & - & + & - & - & - \\
& Akar & - & - & - & + & - \\
\multirow{5}{*}{ Paria } & Batang & - & - & + & - & - \\
& Daun & - & +++ & + & + & - \\
\multirow{5}{*}{ Asam } & Akar & - & - & - & + & - \\
& Batang & + & - & - & - & - \\
& Daun & ++ & ++ & - & - & - \\
& Akar & - & + & ++ & + & - \\
& Batang & - & + & ++ & + & - \\
\hline & Daun & - & ++ & - & - & - \\
\hline
\end{tabular}

Keterangan: $+=$ mengandung metabolit skunder, - = tidak mengandung metabolit sekunder

Tabel 3. Hasil uji aktivitas antibakteri E. coli dan S. aureus

\begin{tabular}{llcccc}
\hline \multirow{2}{*}{ Tanaman } & \multicolumn{2}{c}{ Sampel } & \multicolumn{2}{c}{ E. coli } & \multicolumn{2}{c}{ S. aureus } \\
\cline { 3 - 6 } & & $\begin{array}{c}\text { Diameter Zona } \\
\text { Hambat }(\mathbf{m m})\end{array}$ & Kategori* & $\begin{array}{c}\text { Luas Zona } \\
\text { Hambat }(\mathbf{m m})\end{array}$ & Kategori \\
\hline Belimbing Wuluh & Akar & 15 & Sangat aktif & 10 & Sedang \\
& Batang & - & Tidak aktif & - & Tidak aktif \\
\multirow{5}{*}{ Seledri } & Daun & - & Tidak aktif & - & Tidak aktif \\
& Akar & 10 & Sedang & - & Tidak aktif \\
& Batang & - & Tidak aktif & - & Tidak aktif \\
Jambu bol & Daun & - & Tidak aktif & - & Tidak aktif \\
& Akar & 15 & Sangat aktif & 13 & Sangat aktif \\
& Batang & 13 & Sangat aktif & 15 & Sangat aktif \\
Paria & Daun & - & Tidak aktif & - & Tidak aktif \\
& Akar & - & Tidak aktif & - & Tidak aktif \\
& Batang & 1 & Lemah & 2 & Lemah \\
& Daun & 1 & Lemah & 3 & Sedang \\
& Akar & 3 & Sedang & 3 & Sedang \\
& Batang & 2 & Sedang & 3 & Sedang \\
& Daun & - & Tidak aktif & 0,5 & Lemah \\
\hline
\end{tabular}

*) Ela, dkk., 1996 
Penelitian sebelumnya menunjukkan kandungan utama pada seledri berupa minyak atsiri, resin, 3- $n$ butyl phthalide, sedanolide, sedanonic anhydride dan sedanenolide [26]. Tanaman asam banyak mengandung asam-asam organik, polisakarida, tanin, maupun saponin [27]. Kandungan metabolit sekunder seperti polifenol, flavonoid, tanin, dan antosianin banyak terkandung dalam jambu bol [28]. Selain mengandung polifenol, alkaloid, dan flavonoid, tanaman paria memiliki kandungan cucurbitacine serta turunan sterol dan saponin [29].

Pengujian aktivitas antibakteri dari ekstrak tanaman terhadap bakteri $E$. coli dan $S$. aureus menghasilkan perbedaan dari diameter zona hambat. Hal ini disebabkan perbedaan kandungan golongan senyawa yang terdapat dalam masing-masing ekstrak tanaman yang disebut sebagai metabolit sekunder. Walaupun ekstrak dari tanaman tersebut memilik kandungan senyawa yang sama, akan memberikan aktivitas yang berbeda sebagai antibakteri. Hal ini disebabkan setiap tumbuhan memiliki perbedaan jenis dan kadar metabolit sekunder yang kemungkinan dapat menyebabkan perbedaan aktivitas antibakteri. Mekanisme terhadap antibakteri yaitu dengan membentuk kompleks dengan protein ekstrak seluler dan terlarut dan dengan dinding mikroba [21].

Senyawa flavonoid bersifat antibakteri melalui penghambatan sintesis asam nukleat, penghambatan fungsi membran sel, dan mengganggu metabolisme sel. Mekanisme kerja flavonoid dalam menghambat sintesis asam nukleat dilakukan melalui cincin B pada flavonoid yang mempunyai peranan penting dalam proses interkelasi atau pembentukan ikatan hidrogen dengan menumpuk basa asam nukleat yang menghambat sintesis DNA dan RNA [23].

Tanin memiliki target pada polipeptida dalam dinding sel bakteri sehingga pembentukan dinding sel menjadi kurang sempurna dan kemudian sel bakteri akan mati. Tanin juga memiliki kemampuan untuk menginaktifkan enzim bakteri serta mengganggu jalannya protein pada lapisan dalam sel [24]. Saponin mengganggu permeabilitas dari membran sel sehingga transport sel menjadi terganggu serta menyebabkan sel menjadi lisis. [19]. Mekanisme alkaloid sebagai antibakteri antara lain bersifat bakterisid atau bakteriostatik dengan cara mengganggu sintesis DNA melalui penghambatan enzim dihidrofolat reductase [25].

Pengujian aktivitas antibakteri menggunakan kloramfenikol sebagai kontrol positif bertujuan sebagai perbandingan efektivitas dari ekstrak tanaman. Kloramfenikol bekerja pada spektrum luas sehingga efektif terhadap bakteri Gram positif maupun Gram negatif. Kontrol positif dibuat dengan konsentrasi 10.000 ppm sama dengan konsentrasi larutan ekstrak uji. Kloramfenikol bertindak dengan jalan menghambat sintesis protein yaitu mengikat sub unit $30 \mathrm{~S}$ pada ribosom sel bakteri dan menghambat aktifitas enzim peptidil transferase dengan cepat tanpa mengganggu sintesis DNA dan RNA. Kerja kloramfenikol dengan melihat kerangka molekul senyawa terdapatnya atom klor dan cincin aromatik, dengan subtituen gugus nitro dengan posisi paradan 2 gugus hidroksil. Adanya struktur tersebut memungkinkan terjadinya interaksi dengan enzim peptidil transferase di ribosom bakteri sehingga terjadi penghambatan kerja enzim tersebut [22].

\section{Kesimpulan}

1. Hasil uji skrining fitokimia metabolit sekunder menunjukan belimbing wuluh mengandung senyawa flavonoid dan tanin, seledri mengandung senyawa flavonoid dan saponin, jambu bol mengandung senyawa flavonoid, tanin, dan saponin, paria mengandung flavonoid dan alkaloid, serta asam mengandung flavonoid, tannin, dan saponin.

2. Hasil uji antibakteri menunjukkan akar belimbing wuluh sangat aktif terhadap bakteri $E$. coli dengan diameter zona hambat $15 \mathrm{~mm}$. Ekstrak akar dan batang jambu bol bersifat sangat aktif terhadap bakteri $E$. coli dengan diameter zona hambat 15 $\mathrm{mm}$ dan $13 \mathrm{~mm}$. Ekstrak batang jambu bol juga sangat aktif terhadap bakteri $S$. aureus dengan diameter zona hambat $13 \mathrm{~mm}$ dan $15 \mathrm{~mm}$.

\section{Ucapan Terima Kasih}

Ucapan terima kasih kepada Fakultas Farmasi Universitas Halu Oleo atas dukungan dan bantuan dalam pelaksanaan penelitian ini.

\section{Daftar Pustaka}

1. Rahayu M, Rugayah, Pengetahuan Tradisional dan Pemanfaatan Tumbuhan Oleh Masyarakat Lokal Pulau Wawonii Sulawesi Tenggara, Berita Biologi, 2007; 8(6).

2. Hasanah N, Sudrajat HW, Damhuri, Etnobotani Tumbuhan Obat Masyarakat Desa Lapandewa Kaindea Kecamatan Lapandewa Kabupaten Buton Selatan, Jurnal Ampibi, 2016, 1(1); 14-20

3. Ihsan S, Kasmawati H, Suryani, Studi Etnomedisin Obat Tradisional Lansau Khas Suku Muna Provinsi Sulawesi Tenggara, Pharmauho, 2016, 2(1); 27-32. 
4. Sahidin, Wahyuni, Kamaluddin M, Suaib, Tanaman Obat Keluarga (TOGA) dan Pemanfaatannya Sebagai Penunjang Kesehatan Masyarakat di Desa Sindangkasih, Pharmauho, 2018, 4(2);43-45

5. Nuralifah, Armadany FA, Parawansah, Pratiwi A, Uji Aktivitas Antibakteri Sediaan Krim Anti Jerawat Ekstrak Etanol Terpurifikasi Daun Sirih (Piper betle L.) dengan Basis Vanishing Cream Terhadap Propionibacterium acne, Pharmauho, 2018, 4(2);30-35.

6. Novard MFA, Suharti N, Rasyid R, Gambaran Bakteri Penyebab Infeksi Pada Anak Berdasarkan Jenis Spesimen dan Pola Resistensinya di Laboratorium RSUP Dr. M. Djamil Padang Tahun 2014-2016, Jurnal Kesehatan Andalas. 2019; 8(Supp.2); 26-32.

7. Brooks GF, Janet SB, Stephen AM, Mikrobiologi Kedokteran Edisi 23, diterjemahkan oleh Mudihardi E, Kuntaman, Wasito EB, Mertaniasih NM, Harsono, S, Alimsardjono L, Jakarta : Penerbit Buku Kedokteran EGC, 2007.

8. Departemen Kesehatan RI, Riset Kesehatan Dasar Tahun 2013, Jakarta: Badan Penelitian dan Pengembangan Kesehatan Kementerian Kesehatan RI, 2013.

9. Badan Pusat Statistik, Provinsi Sulawesi Tenggara dalam Angka 2016, Kendari: BPS Provinsi Sulawesi Tenggara, ISSN: 0215-2304, 2016.

10. Imrawati, Baitz M, Jannah M, Uji Aktivitas Antioksidan Ekstrak Etanol Daging Buah Asam (Tamarindus indica L.) Asal Kota Bima Nusa Tenggara Barat dengan Metode DPPH, Journal of Pharmaceutical and Medicinal Sciences, 2016, 1(2);75-78

11. Siska, Armenia, Arifin H, Akar seledri (Apium graveolens L) sebagai obat antihipertensi: efektivitas fraksi etanol air dan etil asetat pada tikus putih jantan hipertensi, Jurnal Bahan Alam Indonesia, 2011, 7(6);337-341

12. Parawansah, Wahyuni, Mahmudah Z, Uji Efek Antipiretik dan Antiinflamasi Ekstrak Etanol Buah Pare (Momordica charantia L.) terhadap Mencit Jantan, Medula, 2016, 4(1);309-315

13. Fauziah N, Novianti, Mustapha I, Pemanfaatan Kayu Batang Jambu Bol (Syzygium malaccense (L). Merr. \& Perry) sebagai Sumber Antioksidan Baru, Farmako Bahari, 2019, 10(1);33-41

14. Andriyanto, Isriyanthi NMR, Sastra EL, Arif R, Mustika AA, Manalu W, Aktivitas Antipiretik
Ekstrak Etanol Buah Belimbing Wuluh (Averrhoa bilimbi) pada Tikus Putih Jantan, Jurnal Veteriner, 2017, 18(4);597-603

15. Pamungkas AR, Indrayudha $P$, Aktivitas Sitotoksik Ekstrak Etanol, Fraksi Etanol-Air, Etil Asetat serta n-Heksana Buah Pare (Momordica charantia) pada Sel MCF-7 secara In-Vitro, Pharmacon, 2019, 16(2);73-82

16. Mulyani S, Laksana T, Analisis Flavonoid dan Tannin dengan Metoda MikroskopiMikrokimiawi, Majalah Obat Tradisional, 2011, 16(3);109-114.

17. Harborne JB, Metode Fitokimia: Penuntun Cara Modern Menganalisa Tumbuhan, Edisi 2, Diterjemahkan oleh Padmawinata K dan Soediro I, Bandung: Penertbit ITB, 2003.

18. Zakaria, Soekamto NH, Syah YM, Firdaus, Aktivitas Antibakteri dari Fraksi Artocarpus Integer (Thunb.) Merr. dengan Metode Difusi Agar, Jurnal Industri Hasil Perkebunan, 2017, $12(2) ; 1-6$

19. Herwandi, Mahyarudin, Effiana, Uji Aktivitas Antibakteri Ekstrak Etanol Annona muricata Linn.terhadap Vibrio cholerae secara In Vitro, Majalah Kedokteran Andalas, 2019, 42(1);11-21

20. Aboul Ela MA, El-Shaer NS, dan Ghanem NB, Antimicrobial evaluation and chromatographic analysis of some essential and fixed oils, Pharmazie, 1996, 51(12);993-994.

21. Septiani, Dewi EN, Wijayanti I, Aktivitas Antibakteri Ekstrak Lamun (Cymodocea rotundata) terhadap Bakteri Staphylococcus aureus dan Escherichia coli, Saintek Perikanan, 2017, 13(1);1-6

22. Kar A, Medicinal Chemistry, New Delhi: New Age International Publishers, 2005.

23. Cushnie TPT, Lamb AJ, Antimicrobial activity of flavonoids, Int J Antimicrob Agents, 2005, 26;343-56.

24. Ngajow M, Abidjulu J, Kamu VS, Pengaruh antibakteri ekstrak kulit batang matoa (Pometia pinnata) terhadap bakteri Staphylococcus aureus secara in vitro. Jurnal MIPA UNSRAT, 2013, 2(2); 128-32.

25. Alhassan AM, Ahmed QU, Averrhoa bilimbi Linn.: A review of its ethnomedicinal uses, phytochemistry, and pharmacology, $J$ Pharm Bioallied Sci., 2016, 8(4);265-71.

26. Khalil A, Nawaz H, Ghania JB, Rehman R, Nadeem F, Value Added Products, Chemical 
Constituents and Medicinal Uses of Celery (Apium graveolens L.) - A Review, IJCBS, 2015, 8; $40-48$

27. Bhadoriya SS, Ganeshpurkar A, Narwaria J, Rai G, Jain AP, Tamarindus indica: Extent of explored potential, Pharmacogn Rev., 2011, 5(9);73-81.

28. Batista AG, da Silva JK, Cazarin CBB, Biasoto ACT, Sawaya ACHF, Prado MA, Júnior MRM,
Red-jambo (Syzygium malaccense): Bioactive compounds in fruits and leaves, LWT - Food Science and Technology, 2017, 76;284-291.

29. Ahamad J, Amin S, Mir SR, Momordica charantia Linn. (Cucurbitaceae): Review on Phytochemistry and Pharmacology, Res. J. Phytochem., 2017, 11(2);53-65.

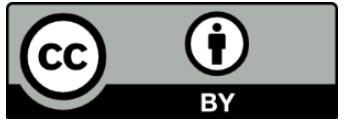

(C) 2020 by the authors; This article is an open access article distributed under the terms and conditions of the Creative Commons Attribution License (http://creativecommons.org/licenses/by/4.0/) 